Endocrinol. Japon. 1969, 16 (1), $29 \sim 36$

\title{
Effects of Testosterone Administration on RNA Synthesis in Kidney of Castrated Rats*
}

\author{
Hidetoshi YAMANAKA, Nobuo FURUYA, Jun SHIMAZAKI \\ AND KEIZO SHIDA \\ Department of Urology, Gunma University School of Medicine, \\ Maebashi, Japan
}

\begin{abstract}
Synopsis
Increase of RNA synthesis in the kidney of castrated rats was observed following testosterone administration. Using whole homogenates, the newly synthesized RNA in the kidney was found most abundantly three hrs. after testosterone administration, followed by a decrease, and returned to the previous level $24 \mathrm{hrs}$. later.

Such newly synthesized RNA consists of both ribosomal RNA and DNA-like RNA, while scarcely any increase of synthesis was observed in soluble RNA. Before the increase in the new synthesis of RNA found in the kidney homogenates, increased synthesis of RNA was observed in the nuclei, mainly in ribosomal RNA. These facts might suggest a selective synthesis of ribosomal RNA in the nuclei in a certain stage, following testosterone administration.
\end{abstract}

Studies of the action of steroid hormone on various target organs revealed many common phenomena. As one of the actions appearing in an early stage following hormone administration, an increase in synthesis of RNA appears to be most characteristic. (Tata, 1966; Williams - Ashman, 1965). New RNA synthesis in the liver initiated by cortisol appears to take place in the nuclei at first, moving subsequently to the cytoplasm. The analysis of this newly synthesized RNA revealed the increased synthesis of DNA-like RNA, ribosomal RNA, and transfer RNA (Kenney et al., 1965). This mode of increase has been observed in other hormone dependent organs such as seminal vesicles, (Wicks et al., 1965;

Received for publication November 7, 1968.

* Dedicated to Professor Yosoji ITO in commemoration of his unselfish devotion for over fifteen years to the advancement of endocrinological science through the editorial management of Endocrinologia Japonica.
Greenman et al., 1965) and uterus (Gorski et al., 1965). According to Drews and Brawerman (1967), the same results were observed in cortisol -stimulated liver nuclei.

It is known that androgen has a certain anabolic action on protein metabolism in the kidney of castrated animals causing an increase of protein and nucleic acids syntheses (Kochakian, 1962; Lattimer, 1942). Kochakian (1965), using mouse kidney, demonstrated an increase of RNA synthesis prior to increase of protein synthesis, concluding that such increase apparently took place in both r-RNA and m-RNA.

This report deals with an analysis of newly synthetized RNA in kidney following testosterone administration using whole homogenates and nuclei by means of extraction under different temperature, separation with methylated albumin Kieselguhr column chromatography and determination of base composition. 


\section{Materials and Methods Animals and Tissue Preparation}

Male albino rats (Sprague-Dawley strain) weighing $200 \sim 250 \mathrm{~g}$ were castrated and fed with standard laboratory chow. $5 \mathrm{mg}$ of testosterone propionate dissolved in $1.2 \mathrm{ml}$ sesame oil was injected intramuscularly. Animals were sacrificed by decapitation at intervals specified in the figures and tables following testosterone propionate administration. Kidneys were removed as quickly as possible and handled on the ice thereafter. Two weeks have elapsed from castration to experiments.

\section{Radioactive Materials}

$2 \mathrm{mCi}$ of ${ }^{32} \mathrm{P}$-sodium phosphate (Daiichi-Kagaku Co.), diluted in $0.9 \%$ saline was injected into cach rat intraperitoneally. All animals were sacrificed 60 mins after the injection of the isotope.

\section{Preparation of RNA in Kidney Whole Homo- genates}

RNA was extracted according to the method of Steele et al. (1965). The kidney was homogenized in a Teflon glass homogenizer with $0.14 \mathrm{M} \mathrm{NaCl} \sim 0.05$ $M$ sodium acetate buffer $(\mathrm{pH} 5.0 \sim 5.1)$ containing $0.6 \%$ sodium dodecylsulfate. For $1 \mathrm{~g}$ tissue, $1.5 \mathrm{ml}$ of buffer was used. After the addition of an equal volume of $90 \%$ phenol $(\mathrm{w} / \mathrm{v})$ containing $0.1 \%$ 8-hydroxyquinoline, the suspension was homogenized for $1 \mathrm{~min}$. The mixture was shaken for ten mins. at $4^{\circ} \mathrm{C}, 25^{\circ} \mathrm{C}$ and $65^{\circ} \mathrm{C}$ respectively, then centrifuged at $10,000 \mathrm{~g}$ for ten mins. After centrifugation, phenol and aqueous layer was separated. After removal of phenol layer, new phenol was added and the mixture was shaken for five mins. each at the same temperature condition. Addition of phenol was repeated again and the aqueus layer was followed by washing with two volumes of ether. The RNA was precipitated overnight at $-20^{\circ} \mathrm{C}$ by addition of two volumes of $95 \%$ ethanol containing $2 \%$ potassium acetate.

\section{Isolation of Nuclei}

Kidney tissue was homogenized with $0.25 \mathrm{M}$ sucrose $\sim 3 \mathrm{mM} \mathrm{MgCl}_{2}$ in a Teflon glass homogenizer, and centrifuged at $700 \mathrm{~g} \times 10$ mins. The precipitate was suspended in $2.4 M$ sucrose $\sim 3.3 \mathrm{~m} M \mathrm{MgCl}_{2}$ approximately 10 times in volume of the original tissue and the suspension was centrifuged at $40,000 \mathrm{~g}$ $\times 60$ mins. The precipitate was further washed once or twice with $0.25 \mathrm{M}$ sucrose $\sim 3 \mathrm{mM} \mathrm{MgCl} 2$ and clear nuclear fraction was obtained. From this suspension, RNA was extracted by the method previously described.

\section{Methylated Albumin Kieselguhr Column Chro- matography of RNA}

Bovine serum albumin was methylated to prepare methylated albumin. The column was prepared according to Mizuno and Takagi (1966) and washed with $100 \mathrm{ml} 0.1 \mathrm{MNaCl} \sim 0.05 \mathrm{M}$ phosphate buffer (pH 6.7). 1 $2 \mathrm{mg}$ of RNA in a concentration of 50 $\mu \mathrm{g} / \mathrm{ml}$ of the buffer solution was applied to the column, followed by rewashing with $200 \mathrm{ml}$ of $0.1 \mathrm{M}$ $\mathrm{NaCl}-0.05 M$ phosphate buffer. Elution was then carried out with $0.1 \sim 1.6 \mathrm{M} \mathrm{NaCl}$ of gradient concentration at a speed of $1 \mathrm{ml}$ per min., using the total volume of $900 \mathrm{ml}$. According to Muramatsu et al. (1966), elution was then carried out with $200 \mathrm{ml}$ of $0.3 \%$ SDS (sodium dodecyl sulfate) $\sim 0.4 \mathrm{M} \mathrm{NaCl}$ phosphate buffer to obtain SDS fraction. After measuring the absorption at $260 \mathrm{~m} \mu$ with UV-autorecorder (Ohtake Mfg. Co.) of the eluate, fractions of $5 \mathrm{~m} l$ were collected and $0.5 \mathrm{~m} l$ aliquots were analyzed for radioactivity.

\section{Analysis of base composition in newly synthe- sized RNA}

After addition of $3-4 \mathrm{mg}$ yeast RNA as carrier to the sample to be analyzed, 0.1 volume of $5 \mathrm{~N}$ perchloric acid was added to precipitate RNA. The precipitated RNA was washed with $0.5 \mathrm{~N}$ perchloric acid and hydrolyzed with $0.3 \mathrm{~N} \mathrm{KOH}$ at $37^{\circ} \mathrm{C}$ for 20 hrs. After the adjustment of $\mathrm{pH}$ to $7.0 \sim 8.0$, the supernatant was chromatographed on Dowex $1 \sim$ Formate column using a linear gradient of formic acid (Osawa et al., 1958). The eluate was fractionated after measurement with UV-Autorecorder. Each mononucleotide peak was concentrated to measure the radioactivity.

\section{Radioactivity measurement}

The sample to be measured was placed in a planchet and evaporated. Measurement was carried out with windless $2 \pi$ gas flow counter (Aloka Inc.) for 3 mins. twice, using the average. The value obtained was corrected for ${ }^{32} \mathrm{P}$ decay.

\section{Analytical methods}

DNA was measured with diphenylamine reaction and RNA with orcinol reaction (Schneider, 1960). Four nucleotide monophosphates were confirmed with UV-absorption spectrum.

\section{Results}

Chromatographic separation of RNA in the kidney whole homogenates with methylated serum albumin Kieselguhr column 


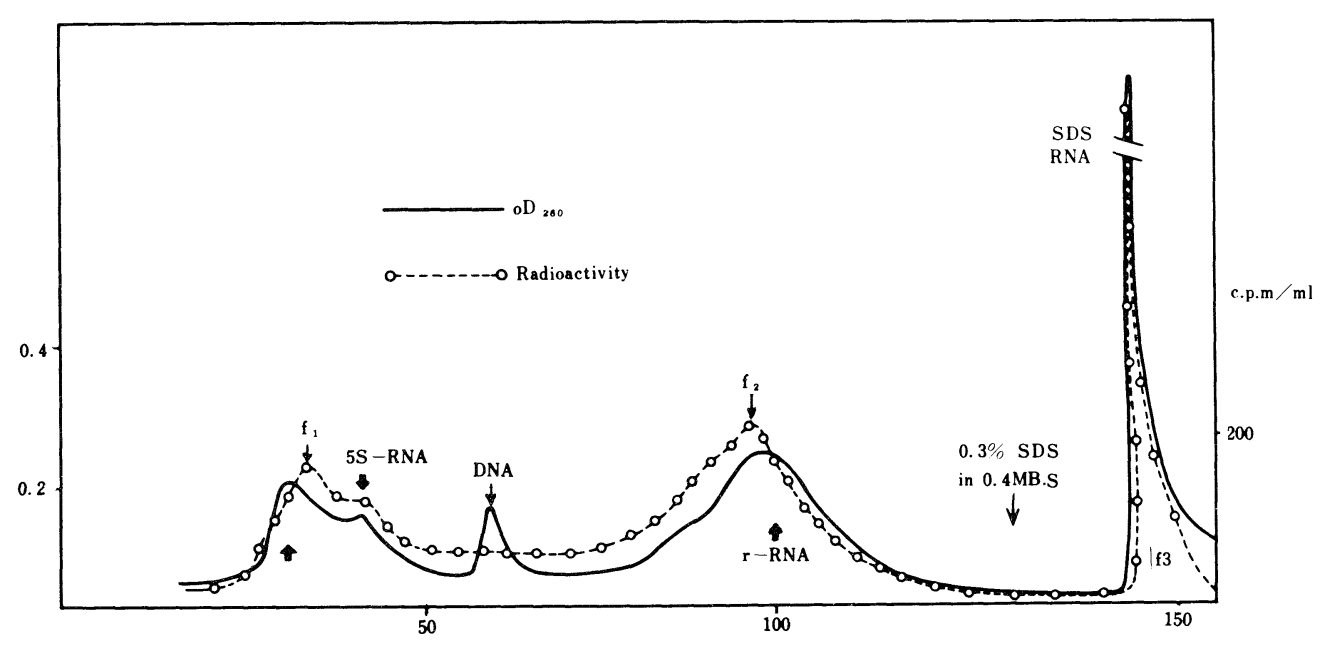

Fig. 1. Elution pattern of RNA in the kidney whole homogenates with methylated serum albumin Kieselguhr column.

Extraction of RNA at $4^{\circ}+25^{\circ}+65^{\circ} \mathrm{C}$ and the method of chromatography are described in the text.

The elution pattern of RNA showed 4 peaks as shown in Figure 1. In the order of elution, s-RNA, 5s-RNA, DNA and r-RNA were obtained. Finally SDS-RNA was obtained by the use of SDS containing buffer. No studies were carried out in the present study on 5s-RNA (Galibert et al., 1965). The position of DNA elution was confirmed by the standard DNA, using the diphenylamine reaction. Three radioactive peaks named $f_{1}, f_{2}$ and $f_{3}$ in order of elution were analysed in the following section. Both U.V. peak of r-RNA and corresponding f2 were identical and showed a single peak as reported by Ito et al. (1966). Tube contents corresponding to $f 1, f 2$ and $f 3$ were obtained for further experiments.

\section{Effects of testosterone administration} on $R N A$ synthesis in the kidney whole homogenates of castrated rats

Table 1 summarizes the specific activity of $f 1$ and $f 2$ fraction of RNA obtained from the kidney whole homogenates 30 mis., 3 hrs., $6 \mathrm{hrs}$. and $24 \mathrm{hrs}$. after testosterone administ-
Table 1. Effects of testosterone administration on the incorporation of ${ }^{32} \mathrm{P}$-sodium phosphate into $\mathrm{f} 1$ and $\mathrm{f} 2$ fraction of RNA in the kidney whole homogenates of castrated rats

\begin{tabular}{rrr}
\hline $\begin{array}{c}\text { Time after testosterone } \\
\text { administration }\end{array}$ & $\mathrm{f} 1^{*}$ & $\mathrm{f} 2 *$ \\
\hline 0 hour & 1.88 & 1.47 \\
0.5 "' & & 1.72 \\
3 " & 1.91 & 2.91 \\
6 " & & 1.79 \\
24 ". & 1.84 & 1.29 \\
\hline
\end{tabular}

All animals were received $5 \mathrm{mg}$ of testosterone propionate at time zero. $32 \mathrm{P}$ - sodium phosphate was injected 60 mins. prior to sacrifice. At time indicated, animals were killed and RNA was extracted at $4^{\circ}+25^{\circ}+65^{\circ} \mathrm{C}$ with phenol.

Date are expressed the specific activity as: $\mathrm{cpm} \times 10^{-3} / \mathrm{ml} / \mathrm{OD}_{260}$ at the peak of each fraction (f1 and $\mathrm{f} 2$ )

ration in comparison with castrated controls. While the specific activity of $\mathrm{f} 1$ showed scarcely any change during experimental periods, that of $\mathrm{f} 2$ increased after $3 \mathrm{hrs}$., followed by a 

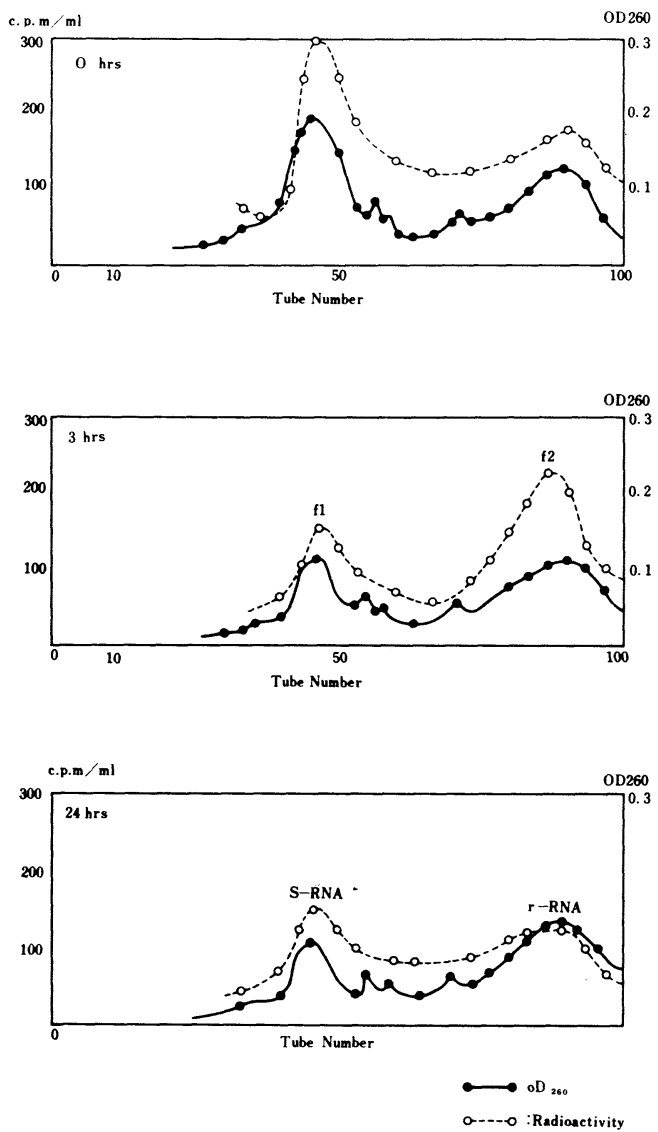

Fig. 2. Effects of testosterone administration on the chromatographic pattern of RNA in the kidney whole homogenates of castrated rats with methylated serum albumin Kieselguhr column. Treatment of animals and extraction of RNA are same as Table 1.

decrease, reaching the level of the castrated control 24 hrs. later. Figure 2 summarizes the elution pattern in the castrated control and 3 and $24 \mathrm{hrs}$. after testosterone administration. As shown, $3 \mathrm{hrs}$. after testosterone administration, $\mathrm{f} 2$ fraction rich of radioactivity was observed. All the elution patterns in the present experiment gave radioactive peaks $\mathrm{f} 1$, $\mathrm{f} 2$ and $\mathrm{f} 3$, and no other radioactivity was noted.
Effects of testosterone administration on the specific activity of $f 2$ fraction in the kidney whole homogenates and analysis of base composition of newly synthesized $R N A$ in $f 2$ fraction

Specific activity of $\mathrm{f} 2$ fraction extracted with phenol at $4^{\circ}+25^{\circ}+65^{\circ} \mathrm{C}$ and $4^{\circ} \mathrm{C}$ in castrated control and testosterone-treated castrated rats was summarized in Table 2 . Testosterone treatment increased the specific activity of each extraction. Moreover, the specific activity of the preparation extracted at $4^{\circ} \mathrm{C}$ was approximately one-half of that of the preparation extracted at $4^{\circ}+25^{\circ}+65^{\circ} \mathrm{C}$, suggesting the presence of newly synthesized

Table 2. Effects of testosterone administration on the specific activity of $\mathrm{f} 2$ fraction of RNA in the kidney whole homogenates of castrated rats with or without testosterone administration under two type of extractions

\begin{tabular}{ccc}
\hline $\begin{array}{c}\text { Testosterone } \\
\text { treatment }\end{array}$ & $\begin{array}{c}\text { Specific activity } \\
4^{\circ}+25^{\circ}+65^{\circ} \mathrm{C}\end{array}$ & $\begin{array}{c}(\text { mean } \pm \text { S.E. })^{* *} \\
{ }^{\circ} \mathrm{C}\end{array}$ \\
\hline $\begin{array}{c}\text { no } \\
\text { hrs. }\end{array}$ & $1.47(1)$ & $0.65(1)^{* * *}$ \\
later* & $2.29 \pm 0.43(3)$ & $0.90 \pm 0.11(3)$
\end{tabular}

RNA was extracted from kidney whole homogenates at $4^{\circ}+25^{\circ}+65^{\circ} \mathrm{C}$ or $4^{\circ} \mathrm{C}$.

*Rats castrated were injected with testosterone propionate $(5 \mathrm{mg} / \mathrm{head})$ intramuscul. 3 hours prior to sacrifice.

** Data are expressed same as Table 1.

***The figures in parenthesis represent the number of experiments.

RNA with high specific activity observed in testosterone-treated ones extracted only at high temperature with phenol. The base composition of the newly synthesized RNA with different extraction temperature was therefore analysed (Table 3). $\mathrm{C}+\mathrm{G} / \mathrm{A}+\mathrm{U}$ ratio gave the value between those of ribosomal RNA and DNA in rat when extraction was performed at $4^{\circ}+25^{\circ}+65^{\circ} \mathrm{C}$. When extraction was carried out at $25^{\circ}+65^{\circ} \mathrm{C}$, values close to the base composition of DNA 
Table 3. Isotopic base composition of $\mathrm{f} 2$ fraction of RNA in the kidney whole homogenates of E testosterone-treated rats under two types of extractions.

\begin{tabular}{lcccccc}
\hline $\begin{array}{c}\text { Extraction } \\
\text { temperature }\end{array}$ & Total ${ }^{32} \mathrm{P}$ in & & $(\%)$ & & \multicolumn{1}{c}{$\mathrm{C}+\mathrm{G}$} \\
\hline $4^{\circ}+25^{\circ}+65^{\circ} \mathrm{C}$ & $\mathrm{C}$ & $30.4 \pm 2.5$ & $19.5 \pm 1.3$ & $23.8 \pm 1.5$ & $26.3 \pm 0.9$ & $1.19 \pm 0.07(3)$ \\
$25^{\circ}+65^{\circ} \mathrm{C}$ & 29.1 & 18.6 & 23.2 & 29.1 & 1.09 & $(1)$ \\
\hline
\end{tabular}

Castrated rats were injected with testosterone propionate $(5 \mathrm{mg} / \mathrm{head})$ i.m., $3 \mathrm{hrs}$. prior to sacrifice. RNA was extracted from kidney whole homogenates at $4^{\circ}+25^{\circ}+65^{\circ} \mathrm{C}$ or $25^{\circ}+65^{\circ} \mathrm{C}$.

Valutes are expressed mean \pm S.E.

The figures in parenthesis represent the number of experiments.

were obtained. From these data, it was concluded that $\mathrm{f} 2$ fraction representing newly synthesized RNA following testosterone administration consisted of a mixture of almost equal parts of r-RNA and DNA-like RNA and that testosterone treatment increased the new synthesis of both r-RNA and DNA-like RNA.

\section{Newly synthesized RNA in SDS frac-} tion

Muramatsu et al. (1966) reported a good yield of DNA-like RNA with the use of methylated serum albumin Kieselguhr column and elution with $0.4 M \mathrm{NaCL}$ - phosphate buffer solution containing $0.3 \%$ sodium dodecyl sulfate after usual $\mathrm{NaCl}$ gradient concentration. SDS-fraction (f3) was therefore collected and was compared with these of $f_{1}$ and $f_{2}$. The spexific activity of $f_{3}$ following testosterone administration showed the same tendency as that of $f_{2}$, reaching the maximum at $3 \mathrm{hrs}$. after testosterone administration, followed by a decrease, returning to the value of castrated control $24 \mathrm{hrs}$. later. RNA of SDS-fraction at $3 \mathrm{hrs}$. after testosterone ad-
Table 4. Differences in the specific activity of SDS (sodium dodecylsulfate) fraction of RNA in the kidney whole homogenates of testosterone-treated castrated rats under various extraction conditions

\begin{tabular}{cc}
\hline \hline Extraction temperature & Specific activity* \\
\hline $4^{\circ}+25^{\circ}+65^{\circ} \mathrm{C}$ & 29.31 \\
$4^{\circ} \mathrm{C}$ & 21.80 \\
$25^{\circ}+65^{\circ} \mathrm{C}$ & 45.44 \\
\hline
\end{tabular}

Castrated rats were treated as Table 2. and RNA was extracted from kiendy whole homogenates at $4^{\circ}+25^{\circ}+65^{\circ} \mathrm{C}, 4^{\circ} \mathrm{C}$ or $25^{\circ}+$ $65^{\circ} \mathrm{C}$.

SDS fraction was obtained by the method described in the text.

*expressed as $\mathrm{cpm} / \mu \mathrm{g}$ of RNA at the peak types of extractions.

ministration was extracted at different temperature of phenol. The conditions under extraction in $25^{\circ}+65^{\circ} \mathrm{C}$ showed the increased specific activity (Table 4). Upon examination of base composition in this SDS-fraction, $\mathrm{C}+$ $\mathrm{G} / \mathrm{A}+\mathrm{U}$ was 1.21 upon extraction at $4^{\circ}+25^{\circ}$ $+65^{\circ} \mathrm{C}$ and corresponding value was 1.03 at $25^{\circ}+65^{\circ} \mathrm{C}$, showing a complete agreement

Table 5. Isotopic base composition of SDS (sodium dodecylsulfate) fraction of RNA in the kidney whole homogenates of testosterone-treated castrated rats under two type of extractions.

\begin{tabular}{cccccc}
\hline \hline $\begin{array}{c}\text { Extraction } \\
\text { temperature }\end{array}$ & $\mathrm{C}$ & $\mathrm{T}$ & $\mathrm{T}$ & $(\%)$ & \multicolumn{2}{c}{$\mathrm{C}+\mathrm{G}$} \\
& $\mathrm{C}^{\circ}{ }^{32} \mathrm{P}$ in & $\mathrm{G}$ & $\mathrm{U}$ & $\mathrm{A}+\mathrm{U}$ \\
\hline $4^{\circ}+25^{\circ}+65^{\circ} \mathrm{C}$ & 27.4 & 17.3 & 27.1 & 28.2 & $1.21(2)$ \\
$25^{\circ}+65^{\circ} \mathrm{C}$ & 27.9 & 19.7 & 22.8 & 29.6 & $1.03(1)$ \\
\hline
\end{tabular}

Treatment of rats and extraction of RNA are same as Table 3. 
Table 6. Effects of testosterone administration on the incorporation of ${ }^{32} \mathrm{P}$-sodium phosphate into $\mathrm{f} 2$ fraction of RNA and its isotopic base composition in the kidney nuclei of catrated rats with or without testosterone administration.

\begin{tabular}{|c|c|c|c|c|c|c|c|}
\hline $\begin{array}{c}\text { Testosterone } \\
\text { treatment }\end{array}$ & $\begin{array}{c}\text { Specific } \\
\text { activity** }\end{array}$ & $\mathrm{C}$ & \multicolumn{2}{|c|}{ Total ${ }^{32} \mathrm{P}$ in $(\%)$} & $\mathrm{U}$ & $\begin{array}{l}\mathrm{C}+\mathrm{G} \\
\mathrm{A}+\mathrm{U}\end{array}$ & \\
\hline no & 102 & 31.9 & 16.3 & 30.9 & 20.9 & 1.69 & $(1)^{* * *}$ \\
\hline $\begin{array}{l}30 \text { mins. } \\
\text { later* }\end{array}$ & 378 & 29.3 & 17.6 & 32.7 & 20.4 & 1.63 & (3) \\
\hline
\end{tabular}

RNA was extracted from the kidney nuclei at $4^{\circ}+25^{\circ}+65^{\circ} \mathrm{C}$.

* Rats castrated were injected with testosterone propionate $(5 \mathrm{mg} / \mathrm{head})$ intramuscul. $30 \mathrm{mins}$. prior to sacrifice.

** Data are expressed as $\mathrm{cpm} / \mu \mathrm{g}$ of RNA.

$* * *$ The figures in parenthesis represent the number of experiments and values in this group are expressed mean.

with $f_{2}$ fraction (Table 5). Based on these results, the SDS fraction obtained in the present experiment appears to be completely identical with $\mathrm{f}_{2}$.

\section{Analysis of base composition in $f 2$ frac- tion of nuclei}

Testosterone was administered in castrated rats, and the kidneys were removed 30 mins. later to isolate the nuclei, from which RNA was extracted with phenol at $4^{\circ}+25^{\circ}+$ $65^{\circ} \mathrm{C}$. In the elution pattern of methylated serum albumin Kieselguhr column, a large radioactive peak was noted in the position corresponding to $f 2$, with an increase of specific activity as compared with the castrated control (Table 6). The base composition of this $\mathrm{f} 2$ fraction was therefore determined. As shown in Table $6, \mathrm{C}+\mathrm{G} / \mathrm{A}+\mathrm{U}$ of castrated control and the corresponding value at 30 mins. after hormone administration was 1.69 and 1.63 respectively, in agreement with that of r-RNA in rat. Based on these data, newly synthesized RNA in the nuclei at 30 mins. after hormone administration in rats was concluded to be mainly r-RNA.

\section{Discussion}

RNA was extracted from the kidney whole homogenates following testosterone administration to analyze newly synthesized
RNA. Increase of both r-RNA and DNA-like RNA were noted, in agreement with many reports on similar analysis so far on various target organs. Before the increase of newly synthesized RNA in the whole homogenate, however, increased synthesis of RNA in the nucleus was already noted. This was mainly r-RNA.

According to Halliburton (1967), as in the case of the present study, the increase of the specific activity of r-RNA was noted in the remaining hypertrophied kidney following unilateral nephrectomy in the early postoperative period. This should be compared with the results in the present report.

According to the reports on the analysis of RNA synthesis in vitro using the nucleus following removal of various target organs after steroid hormone administration (Liao et al., 1966a; Liao and Lin, 1967; Liao et al., 1966b; Trachewsky and Segal, 1967, 1968), both the RNA polymerase of the prostate following testosterone administration and RNA polymerase of the uterus following estradiol-17 $\beta$ administration represented RNA selectively rich in $\mathrm{C}+\mathrm{G}$.. This might be plausible that synthesis of r-RNA was selectively increased in the nuclei at least in certain condition, in agreement with the increase of the new synthesis of r-RNA in the nuclei following hormone administration in the present report. Furthermore, upon measurement of $\mathrm{Mg}^{++}$- stimulated RNA polymerase 
and $\mathrm{Mn}^{++}-\left(\mathrm{NH}_{4}\right)_{2} \mathrm{SO}_{4}$ - stimulated RNA polymerase separately in the in vitro assay method following hormone administration (Tata and Widnell, 1966), $\mathrm{Mg}^{++}$- stimulated RNA polymerase showed earlier and more pronounced rise than $\mathrm{Mn}^{++}-\left(\mathrm{NH}_{4}\right)_{2} \mathrm{SO}_{4}$ stimulated RNA polymerase in both the uterus (Hamilton et al., 1968a, b) and the liver (Ichii, 1967). Since the product of $\mathrm{Mg}^{++}$stimulated RNA polymerase is r-RNA, the action of steroid hormones in increased RNA synthesis might possibly consist of an early and selective stimulation of r-RNA synthesis.

Recently, Avdalovic and Kochakian (1968) who measured RNA polymerase in the nuclei of the kidney following testosterone administration after separating into the $\mathrm{Mg}^{+}$and $\mathrm{Mn}^{++}-\left(\mathrm{NH}_{4}\right)_{2} \mathrm{SO}_{4}$ - stimulated conditions, reported similar conclusion which is of interest as compared with the above mentioned results.

Comparison of SDS-RNA with $\mathrm{f} 2$ fraction which is identical with r-RNA in the kidney whole homogenates failed to reveal any difference in the course of the specific activity and base composition. SDS-RNA and $\mathrm{f} 2$ thus appeared to be identical. Under the conditions of the present experiment, DNA-like RNA and r-RNA were completely eluted upon addition of sodium dodecyl sulfate in rat kidney RNA.

\section{Acknowledgement}

The authors express deep thanks to Miss F. Machida for her technical assistance in the present experiments.

This work was supported in part by a Grant-in-Aid for Cancer Research from the Ministry of Health and Welfare of Japan.

\section{References}

Avdalovic, N. and C. D. Kochakian (1968). 3rd Internat. Congress Endocrinol. (Mexico), Excerpta med. 157126.

Drews, J. and G. Brawerman (1967). J. Biol. Chem. 242, 801.
Galibert, F., C. J. Larseu, J. C. Lelong and M. Boiron (1965). Nature 207, 1039.

Gorski, J., W. D. Noteboom and J. A. Nicolette (1965). J. Cell. Comp. Physiol. 66, 91 (suppl.).

Greenman, D. L., W. D. Wicks and F. T. Kenney (1965). J. Biol. Chem. 240, 4420.

Halliburton, I. W. The 470th Meeting of Biochem. Society (England). (1967).

Hamilton, T. H., C. C. Widnell and J. R. Tata (1968a). J. Biol. Chem. 243, 1968.

Hamilton, T. H., C. S. Teng and A. R. Means (1968b). Proc. Natl. Acad. Sci. 59, 1265.

Ichii, S. (1967). Saishin Igaku. 22, 2424 (in Japanese).

Ito, Y., H. Yamanaka and K. Shida (1966). The Gunma J. Medical Sci. 15,3, 142.

Kenney, F. T., W. D. Wicks and D. L. Greenman (1965). J. Cell. Comp. Physiol. 66, 125 (suppl.).

Kochakian, C. D. (1962). Endocrinology 70, 99.

Kochakian, C. D. Mechanisms of Hormone Action, P. Karlson (Ed.), Acad. Press, N. Y. and Lond., p. 192 (1965).

Lattimer, J. K. (1942). J. Urol. 48, 778.

Liao, S., R. W. Barton and A. H. Lin (1966a). Proc. Natl. Acad. Sci. 55, 1593.

Liao, S., A. H. Lin and R. W. Barton (1966b). J. Biol. Chem. 241, 3869.

Liao, S. and A. H. Lin (1967). Proc. Natl. Acad. Sci. 57, 379.

Mizuno, S. and M. Takagi (1966) Protein, Nucleic Acids and Enzymes 11, 470 (in Japanese).

Muramatsu, M., J. L. Hodnett and H. Busch (1966). J. Biol. Chem. 241, 1544.

Osawa, O., K. Takata and Y. Hotta (1958). Biochim. Biophys. Acta 28, 271.

Schneider, W. C. (1960). Methods in Enzymol. 3,680 .

Steele, W. J., N. Okamura and H. Busch (1965). J. Biol. Chem. 240, 1742.

Tata, J. R. (1966). Prog. Nucleic Acid Res. 5, 191.

Tata, J. R. and C. C. Widnell (1966). Biochem. J. 98, 604. 
Trachewsky, D. and S. J. Segal (1967). Biochem. Biophys. Res. Comm. 27, 588. Trachewsky, D. and S. J. Segal (1968). European J. Biochem. 4, 279.
Wicks, W. D., D. L. Greenman and F. T. Kenney (1965) J. Biol. Chem. 240, 4414. Williams-Ashman, H. G. (1965). Cancer Res. $25,1096$. 